\title{
ALKALOIDS OF THE ROOTS OF THALICTRUM FOETIDUM
}

S. Abdizhabbarova, Z. F. Ismailov, and S. Yu. Yunusov

Khimiya Prirodnykh Soedinenii, Vol. 4, No. 5, pp. 330-331, 1968

From the roots of Th. foetidum L. we have previously isolated $0.3 \%$ of combined alkaloids, $0.1 \%$ of which consists of quaternary bases [1] and $0.2 \%$ of tertiary bases. The tertiary bases have been separated into phenolic and nonphenolic fractions, and two new alkaloids have been obtained. When the nonphenolic fraction was treated with ethanol, prismatic crystals of a base (I) with $\mathrm{mp} 141^{\circ}-142^{\circ} \mathrm{C}$ (decomp.), $[\alpha]_{\mathrm{D}}^{15}+69^{\circ}$ (c 1.0; ethanol) deposited. The homogeneity of the base (I) was confirmed by TLC on a nonfixed layer of alumina in the chloroform-ethyl acetate (1 : 1) system.

UV spectrum in ethanol: $\lambda_{\max } 260,348, \mathrm{~m} \mu(\log \varepsilon 4.58,3.86)$; IR spectrum: 920, 1030, $1050, \mathrm{~cm}^{-1}\left(\mathrm{CH}_{2} \mathrm{O}_{2}\right)$.

In the NMR spectrum of (I) taken on a JNM-100/100 MHz instrument in deuterochloroform ( $\tau$-scale) signals are observed for the protons of a $\mathrm{N}$-methyl group at 7.80 , for four methoxy groups at $6.60,6.50,6.39$, and 6.24 , and for a methylenedioxy group at $4.07 \mathrm{ppm}$. mol. wt. 648 (mass spectrometry).

The data given above and the elementary analysis enable us to establish for the base (I) the composition $\mathrm{C}_{38} \mathrm{H}_{36} \mathrm{O}_{8} \mathrm{~N}_{2}$ and the developed formula $\mathrm{C}_{32} \mathrm{H}_{19} \mathrm{~N}\left(\mathrm{~N}-\mathrm{CH}_{3}\right)\left(\mathrm{OCH}_{3}\right)_{4}\left(\mathrm{CH}_{2} \mathrm{O}_{2}\right)(-\mathrm{O}-)_{2}$. We have called the base thalfine.

The mother liquor after the isolation of thalfine was chromatographed on alumina. The benzene fractions (16-30) showed two spots, 'one of which corresponded to thalfine. Treatment with ethanol isolated thalfine, and from the mother

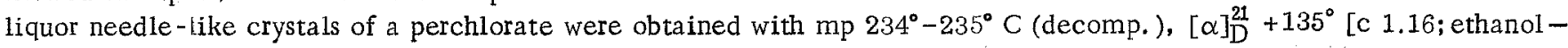
water $(2: 1)]$. The hydrochloride formed prisms with $\mathrm{mp} 223^{\circ}-226^{\circ} \mathrm{C}$ (decomp., water). Decomposition of the perchlorate gave an amorphous base (II) with $\mathrm{mp} 117^{\circ}-118^{\circ} \mathrm{C},[\alpha]_{\mathrm{D}}^{16}+115^{\circ}$ (c 0.95 , ethanol). UV spectrum in ethanol: $\lambda_{\max }$ $282 \mathrm{~m} \mu(\log \varepsilon 3.76)$. IR spectrum: $3600-3300 \mathrm{~cm}^{-1}$ (hydroxy group), $1030,920 \mathrm{~cm}^{-1}$ (methylenedioxy group).

The NMR spectrum of the base (II) showed signals for protons of two N-methyl groups at 7.70 and $7.46 \mathrm{ppm}$, of four methoxy groups at $6.66,6.57,6.34$, and $6.20 \mathrm{ppm}$, and of a methylenedioxy group at $4.20 \mathrm{ppm}$.

On the basis of the above data and its elementary analysis, substance (II) has the composition $\mathrm{C}_{39} \mathrm{H}_{44} \mathrm{O}_{8} \mathrm{~N}_{2}$ and the developed formula $\mathrm{C}_{32} \mathrm{H}_{24}\left(\mathrm{~N}-\mathrm{CH}_{3}\right)_{2}\left(\mathrm{OCH}_{3}\right)_{4}\left(\mathrm{CH}_{2} \mathrm{O}_{2}\right)(\mathrm{OH}) \cdot(-\mathrm{O}-)$. We have called the base II thalfinine.

\section{REFERENCE}

1. Kh. G. Pulatova, S. Abdizhabbarova, Z. F. Ismailov, and S. Yu. Yuntsov, KhPS [Chemistry of Natural Compounds], 4, 59, 1968.

23 April 1968

Institute of the Chemistry of Plant Substances: AS UzSSR

UDC 547.944.1

\section{THE STRUCTURE OF ERVINCININE}

D. A. Rakhimov, V. M. Malikov, and S. Yu. Yunusov

Khimiya Prirodnykh Soedinenii, Vol. 4, No. 5, p. 331, 1968

Continuing our investigation of the alkaloids of the epigeal part of Vinca erecta Rgl. et Schmalh., we have isolated vincaridine and a new base-ervincinine $[1,2]$. A comparison of the UV, IR, NMR, and mass spectra, and some of the chemical properties of vincaridine and picrinine has established the identity of these substances [3].

Ervincinine has the composition $\mathrm{C}_{22^{2}} \mathrm{H}_{26} \mathrm{O}_{4} \mathrm{~N}_{2}$, mol. wt. 382 (by mass spectrometry), mp $247^{\circ}-248^{\circ} \mathrm{C}$ (decomp.) from methanol), $[\alpha]_{\mathrm{D}}^{22}-80.5^{\circ}$ (c 0.39 ; chloroform). UV spectrum: $\lambda_{\max }$ (ethanol) $250,330 \mathrm{~m} \mu$ (log $\varepsilon 4.08$, 4.18), which is characteristic for $\alpha$-methyleneindoline alkaloids. IR spectrum: $3265 \mathrm{~cm}^{-1}(\mathrm{NH}-), 1685 \mathrm{~cm}^{-1}$ (ester carbonyl group conjugated with a double bond), and $840 \mathrm{~cm}^{-1}(1,2,4$-trisubstituted benzene ring). 